\title{
A New Enzymatic Method for the Estimation of Inorganic Phosphate in Native Sera
}

\author{
By Eva N. Fawaz and Asdghig Tejirian \\ Department of Pbarmacology, Scbool of Medicine, American University Beirut, Beirut Lebanon
}

(Eingegangen am 6. September 1971)

\begin{abstract}
A new enzymatic method for the determination of inorganic phosphate $\left(P_{1}\right)$ is described. It utilizes a rcaction of the EMBDEN-MEYERHOF pathway in which triosephosphate takes up $P_{1}$ to form glycerate-1,3-diphosphatc. It was developed for use with nondeproteinized sera containing high amylase activity. The previously described method based on phosphorolysis of glycogen is not satisfactory in such instances and is only half as sensitive as the new method. As the increased sensitivity requircs purer reagents, a procedure for removal of contaminating inorganic phosphate and pyrophosphate is given.
\end{abstract}

Es wird eine neue enzymatische Methode für die Bestimmung von anorganischem Phosphat $\left(P_{1}\right)$ beschrieben. Sie beruht auf der Reaktion des EMBDEN-MEYerhof-Weges, in der Triosephosphat anorganisches Phosphat aufnimmt und Glycerat-1,3-diphosphat bildet. Sie wu de für nicht enteiweißte Seren mit hoher Amylaseaktivität entwickelt. Die zuvor beschriebene Methode, die auf der Phosphorolyse von Glycogen beruht, ist hierfür nicht brauchbar und nur halb so empfindlich wie die neue Methode. Da die höhere Empfindlichkeit reinere Reagenzien erfordert, wird eine Vorschrift für dic Entfernung von anorganischem Phosphat und Pyrophosphat als Verunreinigung angegeben.

An enzymatic method for the estimation of inorganic phosphate $\left(P_{t}\right)$, previously reported from this laboratory (1), utilized glycogen and the enzyme phosphorylase ${ }^{1}$ ) to esterify $P_{1}$. The product of this reaction, glucose-1-phosphate, converted .via glucose-6-phosphate to gluconolactone-6-phosphate, was measured by the amount of NADP reduced. This method, which will be referred to hereafter as the glycogen method, is very satisfactory for the analysis of protein-free extracts of tissues as well as native, i. e. not deprotein- ised human sera. It is unsatisfactory, however, for use with native sera of such common experimental animals as dogs, rats, etc., as these have a very high amylase activity. Amylase breaks down glycogen and thus "consumes" part or most of the substrate that ought to be present in excess throughout the determination. To circumvent the above difficulty a new method was developed which utilizes the second reaction of the glycolytic pathway where $P_{i}$ is esterified at substrate level, namely, the reaction of triosephosphate dehydrogenase:

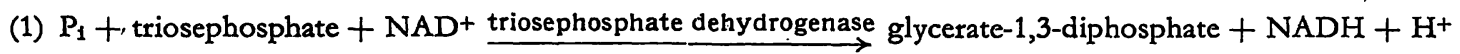

Coupled with it are the following reactions:

(2) glycerate-1,3-diphosphate + ADP phosphoglycerate kinase glycerate-3-phosphate + ATP

(3) ATP + glucose hexokinase glucose-6-phosphate + ADP

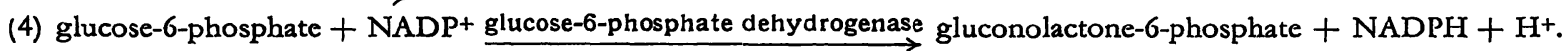

In the first reaction the esterification of $P_{1}$ results in reduction of NAD. The product of esterification donates its phosphate to ADP in reaction (2). Reaction (3) and (4) make use of the ATP generated to reduce NADP. Therefore, for every mole of $P_{1}$ esterified, 1 mole of NAD and another of NADP are reduced. Originally, glyceraldehyde-3-phosphate served as substrate. Later on, glyceraldehyde-3-phosphate was generated from dihydroxyacetone phosphate, and finally from fructose-

1) Enzymes: Phosphorylase (EC 2.4.1.1), Amylase (EC 3.2.1.1), Triosephosphate dehydrogenase (EC 1.2.1.12), Phosphoglycerate kinase (EC 2.7.2.3), Hexokinase (EC 2.7.1.1), Glucose-6-phosphate dehydrogenase (EC 1.1.1.49), Inorganic pyrophosphatase (EC 3.6.1.1), Triosephosphate isomerase (EC 5.3.1.1), Glycerol-3phosphate dehydrogenase (EC 1.1.1.8), Aldolase (EC 4.1.2.13), Alkaline phosphatase (EC 3.1.3.1), Lactate dehydrogenase (EC 1.1.1.27), Fructose-1,6-diphosphatase (EC 3.1.3.11), Phosphoglucomutase (EC 2.7.5.1). 1,6-diphosphate, which proved even better. Each of the three glycolytic intermediates gives satisfactory results, but we have abandoned the use of the trioses since fructose-1,6-diphosphate is stable and more economical.

Finally, it is important to emphasize that the new method, which will be referred to as the triosephosphate method, measures not only $P_{1}$, but also inorganic pyrophosphate $\left(\mathrm{PP}_{\mathrm{1}}\right)$. This is due to the fact that commercially available hexokinase (see reaction 3 ) is contaminated with inorganic pyrophosphatase. In our experience native sera do not contain any $\mathrm{PP}_{\mathrm{i}}$ nor its phosphatase. In tissues, however, $\mathrm{PP}_{1}$ undoubtedly plays an important role. In this communication, therefore, we discuss the triosephosphate method only as applied to sera, and data on $\mathrm{P}_{1}$ and $\mathrm{PP}_{1}$ content of tissues will be published separately. 


\section{Experimental}

Preparation of samples for analysis

Samples of hloud from cxperinental animals werc obtained by heirt puncture and transferred to narrow plastic centrifuge tubes, calpacity ca. $0.5 \mathrm{ml}$. Fifteen min. at room temperature vere allowed for clotting. Sereral of the plastic tubes were tightly packed in a reqular size centrifuge tube and centrifuged for $15 \mathrm{~min}$. at $2000 \mathrm{rpm}$. Hunsin simples were collected from a drop of blood by meatus of a Marburg Mlicroliter pipette of $50 \mu \mathrm{l}$ capacity (obminable from lippendorf Gerärebau, Hamburg, Germany). The plastic tip IIas plugged with plasticine to prevent leakage, then disernnnected from the pipette. After elotting of the blood, the (ii) "las placed in a round-buttom centrifuge tube, cushioned with plasticine and centrifuged.

\section{Reaycnts and their purification}

.1II reagents Werc obtained from Bochringer-Mannhein (Gormany) except for BDTA and glyeogen which were purchased from Merek Co. (Datmstadt, Germany). Glass redistilled water was used for preparing solutions and for rinsing glassware.

The suecess of the triosephosphate method depends mainly upon the quality of the reagents, hence the necessity of choosing them catctull: The degrce of contamination iwith phosphates nuust be checked, and this is best done by the method of Frske and SurBAroll (2). In our experience, the following products of Bochringer contain more phosphate than is pemissible: glucoser phosphatc dchyldrogenase, phosphoghreerate kinase and fructose 1,6-diphosphatc. From these, the contaminating phosphate is precipitated itith magnesium acetate. $N .1 D P$ and ADP contain varying amouns of $\mathrm{P}_{i}$, but it is possible to select suitable pteparations. ADP powder mar also contain $2 P_{i}$, thus it is recommendod that ADl solutions be tested by the glycogen method $(1,3)$. The lattet measures $P_{i}$ and, after addition of motsanic proophosphatase, also PP. If one of the trioses namely slycetaldehrde-3-phosphate or dihydroxy acetone phosphate, is to be used as substrate instead of fructose-1,6-diphosphate, its commercial derivative must be carctully hydrolysed. Prolonged hydrolysis as well as prolonged storage increase $p_{i}$ duc to partial docomposition of the free, labile ester.

\section{Hydrolysis of commercial triosephosphates}

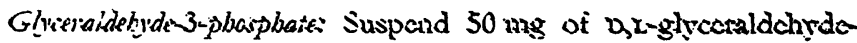
3-phowphate diethylacetal (Ba salt) in $2 \mathrm{ml}$ of $\mathrm{H}_{2} \mathrm{O}$ in a slassstoppered ecritrituge tubs Add $1 \mathrm{~g}$ of dotrax-50 $\mathrm{H}^{+}(100$ to 200 mesh), shake rigorously until all pordet goes into solution, centrituge and decant supernatant. Wash doncex tesidue with $0.6 \mathrm{ml} \mathrm{H}_{2} \mathrm{O}$ and add nashings to the main portions. The combined solutions, which hare a pH of around 1.j, ate incubated at $39^{\circ}$ to $40^{\circ}$ tor 18 houts onty. Determine D-ghyectaldehyde-3 -phosphate (with triosephosphate isomerase and streetol3-phosphate dehydrogenase) and analyze for $P_{i}$ (the contamination with the latter should not exicced $50 \mathrm{~kg} ; \mathrm{ml}$ ). Store the acidic solution of glyceraldchydev-phosphate frozen and use within 2 months The triosephosphate method calls for ca. 0.2 , amolc of D-glycetalde hyde $\hat{3}$-phosphate pet $P_{i}$ determination cartied out in 2 rolume of $1.2 \mathrm{ml}$.

Dilydrayacetone phasphate: Dissolve $15 \mathrm{~ms}$ dihydtoxyacetone phosphate fimcthylketal, dicyclohexylammonium salt $-\mathrm{H}_{2} \mathrm{O}$ in $2 \mathrm{ml}$ of $\mathrm{H}_{2} \mathrm{O}$, atd $0.3 \mathrm{~g}$ dowex- $30 \mathrm{H}^{+}$, shake for a fer minutes, centrifuge and dicant. Wash don'cx tesiduc with $0.6 \mathrm{ml} \mathrm{H}_{2} \mathrm{O}$, combinc washings with the main portion and let stand at $30^{\circ}-40^{\circ}$ for 4 hours only. Solutiors so prepared have a very low initial $P_{i}$ entent. They must be analysed (slyecrol3-phosphate dehydtogenasc) and used within a month of frozen storage. The amount required is 0.45 . 4 mole per determination (vol $1.2 \mathrm{ml}$ ).

Procedure for precipization of contaminating phos phates

Magnesium ammonium phosphates are practically insoluble. This property sertea as basis for purifying the reagents. To enzyma, which are as a rule suspendad in $\mathrm{AH}_{4} \mathrm{~h}_{2} \mathrm{SO}_{4}$, ane simply needs to add an excess of $\mathrm{Mg}^{++}$. Magnesium acetate is most suitable for this purpose, as its anion is harmless, and it also provides a convenient $\mathrm{pH}$ of around 7.5 at which the precipitations are best carried out. This technique of precipitation is superior to dialysis or washing procedures usually applied to enzymes. In our experience it is also superior to recrystallizations of a substrate such as fructose-1,6-diphosphate.

Glucose-6-phospbate debjdrogesase. The Boehringer suspension of $5 \mathrm{mg}$ enzyme protein/ml usually coneains ca. $1 \mathrm{mg} P_{i} / \mathrm{ml}$ and most of it is removed as follows: Mix in a small centrifuge tube $100 \mu \mathrm{l}$ of the enzyme and $400 \mu \mathrm{l}$ of $0.4 \mathrm{M}$ magnesium acetate. Place the tube in ice and scratch the wall with a glass rod for $5-7 \mathrm{~min}$. to initiate precipimation. Keep for additional $15 \mathrm{~min}$. in ice and centrifuge in the cold. Analyze supernatant for $P_{1}$ content and assay enzyme activity.

Recently, we hare obtained from Bochringer a preparation of glucose-6-phosphate dehydrogenase which concains as little as $1 / 5$ th the usual amount of $\mathbf{P}_{\mathbf{i}}$. This product is suimble for direct use with the glyoogen method but still unsuitable for the triosephosphate method, as the latter is more sensitive. Since it is more difficult to get rid of contaminating $P_{\mathbf{1}}$ when its initial concentration is so lor, follow the procedure described above, but allow 2 to 3 days for precipitation with occasional scratching. If it is not convenient to wait so long, substitute $0.8 \mathrm{M}$ magnesium acetate for the usual $0.4 \mathrm{M}$ and the precipitation will not require more time than 15 min. 2s in the case of the more highly contaminated enzyme. In our experience the magnesium acetate treated glucose-6-phosphate dehydrogenase is as stable as the original suspension.

Pbasphoghunerate kinase. The Bochringer product is 2 suspension in $\left(\mathrm{NH}_{4}\right)_{2} \mathrm{SO}_{4}$ and $0.04 \mathrm{M} \mathrm{Nia}_{4} \mathrm{P}_{2} \mathrm{O}_{4}$. According to our analyses over the past fer years, $1 \mathrm{ml}$ containing $10 \mathrm{mg}$ enzyme protein gires between 2.0 and $2.5 \mathrm{mg} P_{i}$ upon hydrolysis in $1 \times \mathrm{HCl}$, around one tenth of it being true $P_{1}$. It is necessary to free the enzyme from $\mathrm{PP}_{i}$, ws hexokinase, which is used in the $P_{i}$ assay strstem, has inorganic pyrophosphatase activity. The following procedure removes both the $\mathrm{PP}_{1}$ and the samall amount of $P_{1}: \mathrm{Mr}$ in a centrifuge rube 200 ul phosphoghycerate kinase, $10 \mathrm{mg}$ enzyme protein! mol, and 300 yll of $0.4 \mathrm{M}$ magnesiom acetate. Inumetse in ice for $5-i$ min., scratch the wall of the tube and let stay in refrigerator for 1-3 days Stir the precipitate, scratch again, let stand for $15 \mathrm{~min}$. in ice to complete the precipitarion and centrifuge in the cold. Analyse the supernatant for $P_{1}$ after bydtolysis in $1 \mathrm{w} \mathrm{HCl}$ (method of Fiske and Stosarow). If the hydralyzable phosphoras is low enough, separate the supermatant. Othervise, stit and keep an additional day or so in tefrigerator, centrifuge and analyze. The concentration in the sopernatant is $4 \mathrm{mg}$ enzyme protein;ml.

The newrest catalogue of Bochringer states that their phosphostrcerate kinase is suspended in $\left(\mathrm{NH}_{4}\right)_{2} \mathrm{SO}_{4}$ and $1 \mathrm{~mm}$ EDTA 4 bur no mention is made of $P P_{3}$, wras the ease in the past. We have obtained most recently such 2 preparation and found that $1 \mathrm{ml}$ of $10 \mathrm{mag}$ enzyrue protein contains sfightly over $0 . \overline{\mathrm{j}} \mathrm{mg}$ of $\mathrm{P}_{\mathbf{I}}$ and $0.2 \mathrm{mg}$ of $\mathrm{PP}$ i phosphorus. The procedure which is recommended for the purification of such 2 prodact, is to mix $100 \mu$ la of the anzyme suspension with $400, \mu 1$ of $0.3 \mathrm{M}$ magnesium acerate and allow 1-3 days for precipitation. Lising these proportions one gets a supernatant of $2 \mathrm{mg}$ enzyme protein/ml.

As a rule, phosphoglycerate kinase mast be rested for acririry to make sure that a good excess is prorided to drive the rwo pro ceding teactions, nemely, ther of aldolase and rriosephosphare dehydrogensise, in the forrera direction.

Fructare-1, 0 -ifphosphete. Dissolve $50 \mathrm{mg}$ fructose-1,6-diphosphate terra-hexylammonioun salt: $10 \mathrm{H}_{2} \mathrm{O}$ in $250 \mu$ of $0.8 \mathrm{~N}$ magnesinm

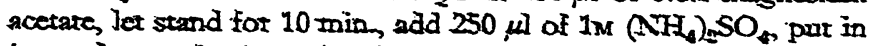
jice and scratch the wall of the centrifuge tribe for 3-7.min. with slass rod. Pat in tefrigermtor and keep for 1-2 days with occasional scratching ( $3-4$ times). Allow $15 \mathrm{~min}$. in ice after last scrarching, centrifuge in the cold. Analyze supernatant for $P_{i}$ and determine fructose-1,6-diphosphave enzyrnatically using aldolases triosephosphare isomerase and stycerol-3-phosphate dehydrogenase. 


\section{Auf sicherem Kurs}
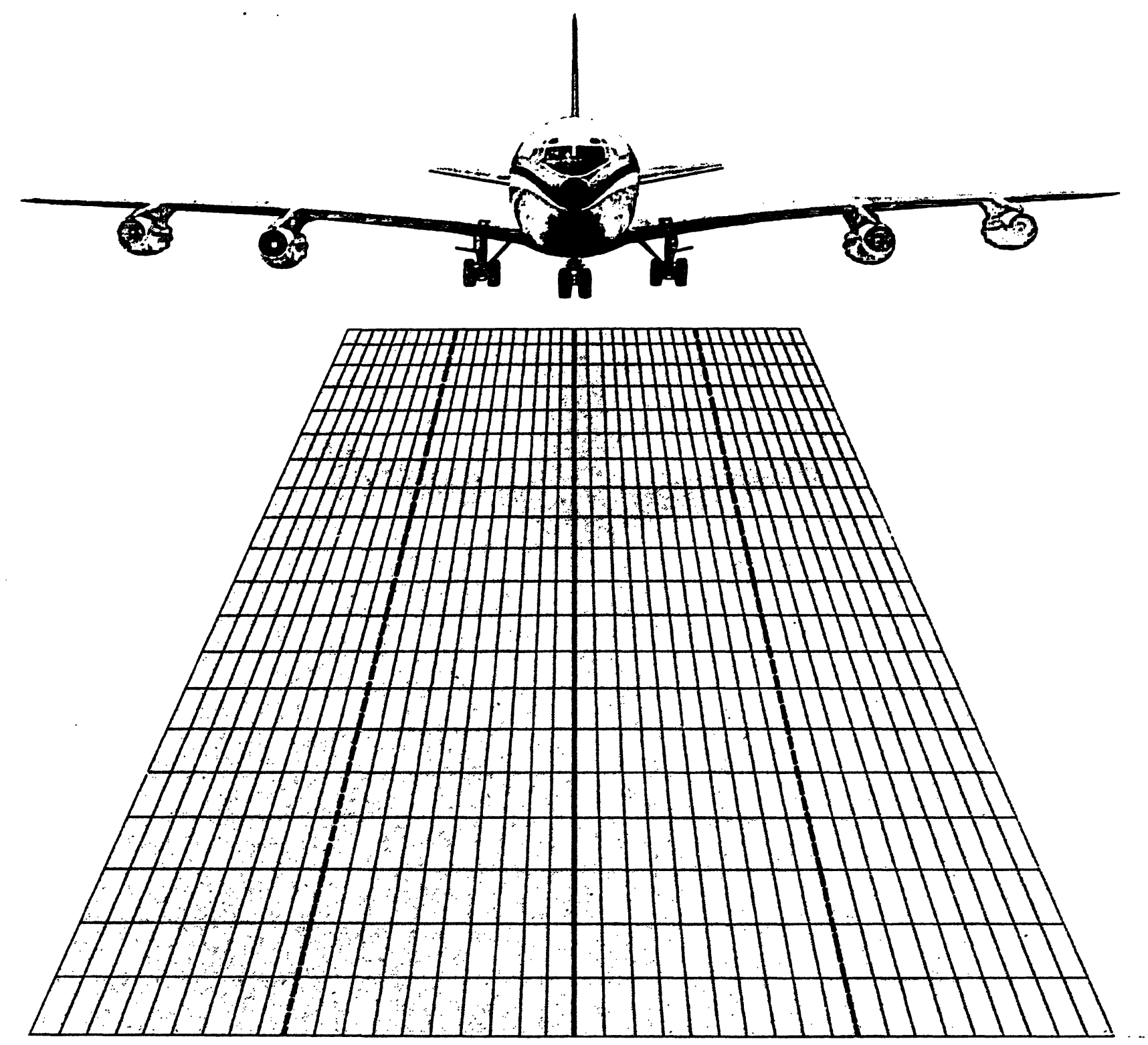

Qualitätskontrolle im klinisch-chemischen Labor mit

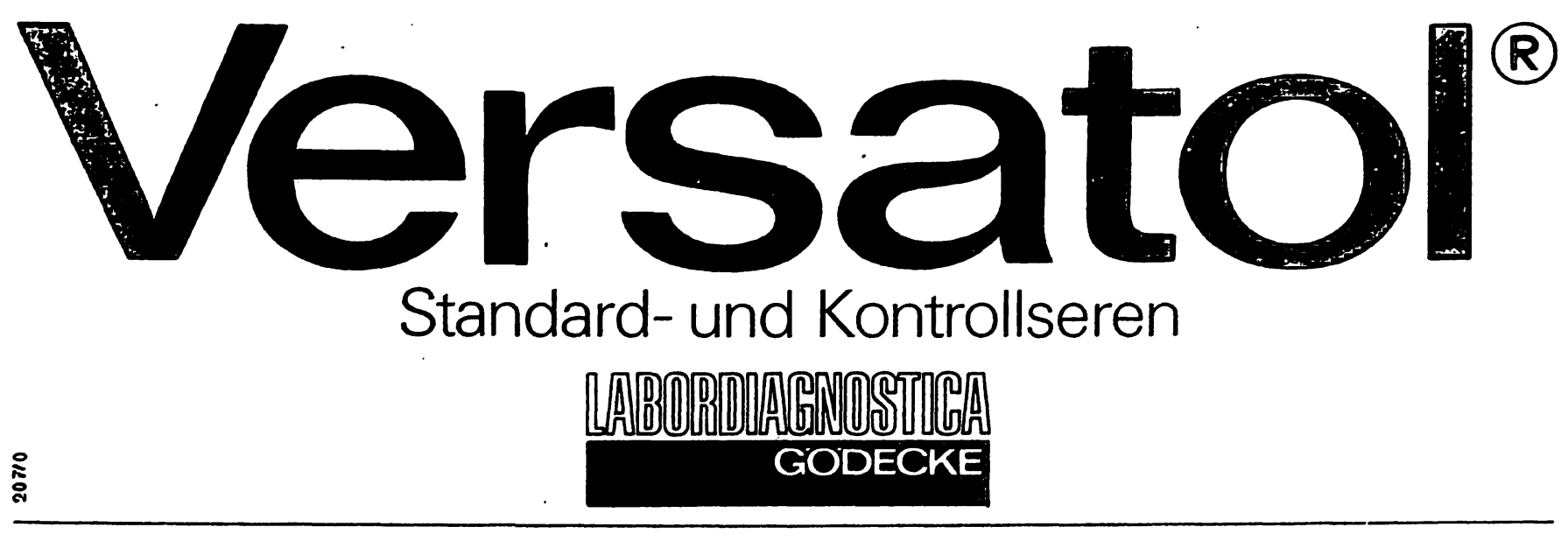




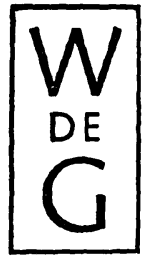

\section{Walter de Gruyter Berlin-New York}

\section{W. Pschyrembel}

\section{Klinisches Wörterbuch}

mit klinischen Syndromen

251., durchgesehene und verbesserte Auflage. Oktav. XVI, 1348 Seiten. Mit 2274 Abbildungen im Text. 1972.

Gebunden DM 36, ISBN 3110036576

Dieses altbewährte klinische Nachschlagewerk entstand unter Mitarbeit einer Gruppe erfahrener Fachärzte und gibt in gedrängter, aber erschöpfender Form Auskunft über Etymologie Diagnostik - Differentialdiagnose und Prognose aller wichtigen Krankheitszu stände und informiert über die neveste Entwicklung der gesamten Medizin und ihre Grenzgebiete sowie über die klinischen Untersuchungs- und Arbeitsmethoden, besonders was deren praktischen Aussagewert angeht.

Der Inhalt des Buches umfaßt alle klinischen Fächer, daneben aber auch die sogenannten theoretischen Fächer Pharmakologie - Mikrobiologie Endokrinologie - Klinische Chemie Enzymologie und Humangenetik, sowie. die Klinischen Syndrome und Eponyme (Stichwörter mit Autorennamen).

\section{O. W. Haseloff \\ E. Jorswieck}

\section{Psychologie des Lernens}

Methoden, Ergebnisse, Anwendungen

2. Auflage. Oktav. VIII, 281 Seiten. 1971. Plastik flexibel DM 19,80 ISBN 3110036916

Diese systematische und moderne Psychologie des Lernens gibt einen Überblick über die Formen und Gesetze des Lernens.

Dabei geht es nicht nur um Gedächtnis und Übung. Vielmehr werden kompetente Informationen über die Bedingungen eines Lernens vermittelt, das den Charakter der Verhaltensänderung und der Neuanpassung hat. Im einzelnen wird dargestellt, wie Lernprozesse im zu Unterrichtenden oder zu Erziehenden ausgelöst und gesteuert werden und wie sich die Speicherung von Informationen sowie die Nevorganisation des Verhaltens vollzieht.

\section{O.W. Haseloff H.-J. Hoffmann \\ Kleines Lehrbuch der Statistik}

Für Naturwissenschaft und Technik, Psychologie, Sozialforschung und Wirtschaft. 4., neubearbeitete und erweiterte Auflage mit 59 Figuren, 99 Tabellen, 1 Anhang statistischer Arbeitstabellen und Übungsaufgaben und 1 Ausschlagtafel. Oktav. XII, 330 Seiten. 1970. Gebunden DM 19,80 ISBN 3110007169

\section{A. Waldeyer \\ Anatomie des Menschen}

Für Studierende und Ärzte, dargestellt nach systematischen, topographischen und praktischen Gesichtspunkten

2 Teile

Teil I: Allgemeine Anatomie - Rücken Bauch - Becken - Bein

7., unveränderte Auflage. Groß-Oktav. $X X, 447$ Seiten. Mit 335 Abbildungen.

1972. Ganzleinen DM 5़6, 二

ISBN 3110039788

Teil II: Kopf und Hals $=$ Auge - Ohr Gehirn - Arm - Brust

6., überarbeitete Aúflage. Mit $\mathbf{4 4 7}$ zum Teil farbigen Abbildungen. GroßOktav. XVI, 603 Seiten. 1970. Ganzleinen DM 62,-

ISBN 3110005956

Dieser Grundriß wird dem Studierenden, dèr eine Verbindung der einzelnen Disziplinen der Medizin zu einem Gesamtgebäude sucht, ein willkommener Helfer sein, der ihn voraussetzungslos von der Zelle über komplizierte morphologische Gegebenheiten bis zu so manchem täglichen Problem des Arztes führt und seine Kenntnisse noch durch die notwendigsten entwicklungsgeschichtlichen und vergleichend-anatomischen $\mathrm{Er}$ gänzungen vertieft. Die einprägsamen schematischen Abbildungen erleichtern inm diesen Weg.

W. Thiel, Graz, in: Klinische Medizin 
A $P_{1}$ determination carried out in a volume of $1.2 \mathrm{ml}$ requires a third of a $\mu$ mole of fructose-1,6-diphosphate as substrate. This amount is generally found in $3 \mu \mathrm{l}$ of the supernatant. The total contamination in these $3 \mu \mathrm{l}$ after the above treatment is around $0.1 \mu \mathrm{g}$ of $P_{1}$. The commercial fructose-1,6-diphosphate may contain $10-20$ times as much and is unsuitable for direct use.

\section{Enzymatic Method}

All measurements are done using a Beckman spectrophotometer model $B$ at $340 \mathrm{~nm}$. Semi-micro cuvettes, light path $10 \mathrm{~mm}$, width $4 \mathrm{~mm}$, are used. All $P_{1}$ determinations are carried out in a final volume of $1.2 \mathrm{ml}$. Marburg microliter pipettes are used for delivery of small volumes of reagents, enzymes and samples.

Five commercially available enzymes are required and it is advisable to use the concentrated preparations in order to minimize the amount of $\left(\mathrm{NH}_{4}\right)_{2} \mathrm{SO}_{4}$ in the assay system. Two highly contaminated cnzymes, glucose-6-phosphate dehydrogenase and phosphoglycerate kinase, need to be purified (see preceding directions). Preparations of hexokinase being slightly contaminated, should be analyzed for $P_{1}$ and the best product selected. The remaining two enzymes, aldolase and triosephosphate dehydrogenase, contain as a rule no impurities of phosphates. Procedures for measuring enzyme activities are provided by the Bochringer firm.

The triosephosphate method operates more efficiently at an alkaline $\mathrm{pH}$. The starting $\mathrm{pH}$ of the buffer required is 8 . As many reagents are added, like NAD, NADP and the 5 enzymes, the $\mathrm{pH}$ decreases and reaches around 7.7. Acidic reagents must be avoided, because if the $\mathrm{pH}$ during the actual measurement is less than 7.7, the, system does not operate quantitatively. With each set of determinations it is necessary to carry a reagent blank and a standard through out the whole procedure. The reagent blank, which contains all the reagents and enzymes, measures their contamination with phosphates. The standard cuvette indicates with what efficiency the system operates and whether the esterification of $P_{1}$ is quantitative.

Procedure: The $P_{1}$ determinations are carried out in $1.2 \mathrm{ml}$ of $50 \mathrm{~mm}$ triethanolamine containing $5 \mathrm{~mm}$ EDTA. The method calls for the following concentrations of reagents in the above buffer: $1 \mathrm{~mm}$ glucose, $0.02 \mathrm{~mm}$ ADP, $0.5 \mathrm{~mm}$ NAD, $0.33 \mathrm{~mm}$ NADP and $5 \mathrm{~mm}$ magnesium acetate. The native sera are added in an amount of $10 \mu \mathrm{l}$ or less and kept for $15 \mathrm{~min}$. in order to allow for inactivation of the serum enzymes. This is followed by introducing the enzymes and finally the assay is started by adding the substrate, namely fructose-1,6-diphosphate. If glyceraldehyde-3phosphate or dihydroxyacetone phosphate is to replace the latter, see "alternative procedures".

For convenience it is suggested that the following reagents be mixed: $500 \mu \mathrm{l}$ Triethanolamine-EDTA buffer $\mathrm{pH} 8$ (Triethanolamine $120 \mathrm{~mm}$, EDTA $12 \mathrm{~mm}$ ), $40 \mu$ l glucose (30 mM), $10 \mu \mathrm{l}$ ADP $\left(2.4 \mathrm{~mm}, \mathrm{ADP} \mathrm{Na} a_{3}\right), 30 \mu \mathrm{l}$ magnesium acetate $(200 \mathrm{~mm}), 10 \mu \mathrm{l}$ NAD (60 mm), $10 \mu 1$ NADP ( $40 \mathrm{~mm}$, NADP Na). These quantities add up to $600 \mu \mathrm{l}$ and are needed per one determination. Prepare enough reagent mixture to pipette $600 \mu \mathrm{l}$ for reagent blank, a standard and each of the unknowns. The volume of enzymes, native serum and substrate required must add up with $\mathrm{H}_{2} \mathrm{O}$ to another $600 \mu \mathrm{l}$. Pipette the reagent mixture, the calculated amount of $\mathrm{H}_{2} \mathrm{O}$, the standard and the sera into appropriate cuvettes. Allow $15 \mathrm{~min}$. for inactivation of enzymes in sera and during that time prepare enzyme mixture. The following quantities of each enzyme are required per determination: $5 \mu$ l glucose-6-phosphate dehydrogenase, $1 \mathrm{mg}$ enzyme protein/ml or amount equivalent to 0.35 units; $5 \mu$ l hexokinase, $2 \mathrm{mg}$ enzyme protein $/ \mathrm{ml}$ if activity not determined, otherwise 0.8 units; $3 \mu \mathrm{l}$ phosphoglycerate kinase, $4 \mathrm{mg}$ enzyme protein $/ \mathrm{ml}$, or amount equivalent to 5 units; $5-7 \mu 1$ triosephosphate dehydrogenase, $10 \mathrm{mg}$ enzyme protein $/ \mathrm{ml}$ if activity has not been determined, otherwise an amount equivalent to 2.5 units; $5-6 \mu \mathrm{l}$ aldolase, $10 \mathrm{mg}$ enzyme protein $/ \mathrm{ml}$, if activity has not been determined, otherwise 0.35 units. Prepare enough mixture for all cuvettes and if desired, include some $\mathrm{H}_{2} \mathrm{O}$ to get a convenient volume for fast delivery (Marburg Pipette). Introduce the enzyme mixture into all cuvettes, measure the absorbance (E) at $340 \mathrm{~nm}$ (wait until steady readings are obtained), then start the assay by adding fructose-1,6-diphosphate $(0.33 \mu$ mole in a volume of $20 \mu \mathrm{l})$. Take measurements every $5 \mathrm{~min}$. for the next $20-30 \mathrm{~min}$. A standard of $0.03 \mu$ mole $P_{i}$ usually gives a $\Delta \mathrm{E}$ of 0.310 within $10-15 \mathrm{~min}$. This value is obtained after correction for contaminating phosphates in reagents and enzymes, and it remains steady although the reactions do not come to a complete stop due to some phosphatase impurity present in the enzyme mixture. The $\triangle \mathrm{E}$ values for sera, as calculated by subtracting the corresponding $\Delta \mathrm{E}$ for the reagent blank, reach also the maximum within 15 to $20 \mathrm{~min}$. and remain steady.

For calculations, let us consider a determination done on rat serum. Twenty min. after adding fructose-1,6-diphosphate, the reagent blank gave a $\Delta \mathrm{E}$ of 0.155 , the standard a $\Delta \mathrm{E}$ of 0.465 and the rat serum a $\Delta \mathrm{E}$ of 0.385 . By subtracting $0.155 \mathrm{from}$ each of the two values, we obtain $\Delta \mathrm{E}=0.310$ for standard, which is theoretical and $\Delta \mathrm{E}=0.230$ for rat serum. Since $10 \mu \mathrm{l}$ of the serum were used for this determination, the content of $P_{1}$ in $\mathrm{mg} / \mathrm{l}$ of rat serum is:

$$
\frac{0.230}{6.22} \cdot 1.2 \cdot \frac{31}{2} \cdot 1000 \cdot \frac{100}{1000}=68.8
$$

(6.22 being the $\mu$ molar extinction coefficient for $\mathrm{NADH}$ and $\mathrm{NADPH}$ at $340 \mathrm{~nm}$ ).

\section{General Remarks and Precautions}

According to the directions given, the magnesium acetate concentration in the buffer is $5 \mathrm{~mm}$. This does not include the extra magnesium introduced with the two enzymes and fructose-1,6diphosphate which are purificd by the precipitation procedure. If the enzymes are treated with 0.8 instead of $0.4 \mathrm{M}$ magnesium acetate to remove phosphates, the $\mathrm{Mg}^{++}$used in the buffer must be reduced to one half. Excess of this ion makes EDTA ineffective and thus if a serum exhibits high alkaline phosphatase activity, some $P_{1}$ splits slowly and gives a gradual increase for $P_{1}$ value of that serum (EDTA inhibits alkaline phosphatase).

Another difficulty is that sera with a very high pyruvate content may show a back-run. A small amount of lactate dehydrogenase present in the system causes a slow reduction of pyruvate and thus a reoxidation of NADH. This was observed with blood serum obtained from a dog heart-lung preparation after severe anoxia. In such a case one may add some $\mathrm{NADH}$ and lactate dehydrogenase before fructose-1,6-diphosphate so as to convert all the pyruvate in the sample to lactate before the actual determination is started.

The use of hemolyzed sera should be avoided as these show high triosephosphate isomerase activity. This enzyme catalyses dihydroxyacetone phosphate formation from glyceraldehyde-3phosphate, the equilibrium being in favor of the former. Thus, part of the glyceraldehyde-3-phosphate generated from fructose1,6-diphosphate becomes unavailable for esterification of $P_{i}$ and the system may not operate quantitatively. If only hemolyzed sera are available, we recommend use of dihydroxyacetone phosphate as starting substrate according to directions given under "Alternative Procedures".

The procedure utilizing dihydroxyacetone phosphate or glyceraldehyde-3-phosphate as substrate should also be applied to analyses of sera which exhibit fructose-1,6-diphosphatase activity or in case one of the commercial enzymes used for $P_{1}$ determination happens to be contaminated with this phosphatase.

Aldolase cleaves fructose-1,6-diphosphate to glyceraldehyde-3phosphate and dihydroxyacetone phosphate. The latter remains unutilized during the determination and it is very important that the commercial enzymes are not contaminated with glycerol3-phosphate dehydrogenase. One way to avoid the interference of this enzyme would be to carry out the $P_{1}$ determination starting with glyceraldehyde-3-phosphate as substrate.

\section{Alternative Procedures}

In some special cases it may be necessary to use one of the trioses as substrate rather than generate it from fructose-1,6-diphosphate. 
The main inconvenience lies in the conversion of the commercial triose into one suitable for use. In case of glyceraldehyde-3-phosphate, the starting product is an insoluble $\mathrm{Ba}$ salt. After Dowex treatment, 18 hours are required to split off the protective ethyl groups. The commercial product of dihydroxyacetone phosphate is a cyclohexylammonium salt. It is soluble and takes only 4 hours to split off the protective groups, but it is far too expensive for routine work. Both free esters are rather unstable and must be frequently analyzed.

The procedure for $P_{1}$ determinations using glyceraldehyde-3phosphate or dihydroxyacetone phosphate as substrate remains the same as when fructose-1,6-diphosphate is used, except for the following minor variations:

If one starts with glyceraldehyde-3-phosphate, the magnesium acetate concentration in the buffer is increased from 5 to $6.3 \mathrm{~mm}$ and aldolase is omitted from the enzyme mixture.

If one starts with dihydroxyacetone phosphate, the initial $\mathrm{pH}$ of the buffer is raised to $\mathrm{pH} \cdot 8.5$, magnesium acetate concentration in this buffer is increased to $6.3 \mathrm{~mm}$ and $5 \mu \mathrm{l}$ of triosephosphate isomerase, $2 \mathrm{mg}$ enzyme protein $/ \mathrm{ml}$, are added together with the other enzymes. Aldolase is excluded from the enzyme mixture.

\section{Results and Discussion}

The colorimetric method of FISKE and SubBarow requires that sera be deproteinized and therefore relatively large samples of blood are needed. This is wasteful when human blood is used and renders experimentation in the case of small animals difficult or impossible. The enzymatic methods are not only more sensitive, but they can be applied to nondeproteinised sera. The glycogen method described earlier, gives excellent results for humans, with a few exceptions. One needs as little as $20 \mu \mathrm{l}$ of serum for a determination. The need for an enzymatic micro-method utilizing a substrate other than glycogen, which would be applicable to laboratory animals, is obvious. The triosephosphate method is the answer to this problem. One reason why it has not been worked out so far, may lie in the unavailability of the proper reagents and enzymes, for although they are all commercially available, their contamination presents serious problems. The inconvenience of preparing free trioses from the commercial products and their relative instability, can be overcome by generating them from fructose-1,6-diphosphate.
Theoretical considerations do not at first sight make this appear possible, as the aldolase reaction which cleaves fructose-1,6-diphosphate has a very unfavorable equilibrium for the formation of the trioses; also, reaction (1), which is supposed to esterify $P_{1}$ quantitatively, does not proceed readily to the right. In nature, however, glycolysing tissues face the same unfavorable equilibria under suboptimal conditions, yet readily produce lactic acid. The new method was made to succeed by the application of alkaline $\mathrm{pH}$ which favors the forward direction of reaction (1). The products of this reaction were withdrawn by means of reactions (2), (3) and (4), the equilibria of which are all far to the right. Under such conditions the system operates quantitavely with fructose-1,6-diphosphate as substrate.

The triosephosphate method has been in use for over 2 years in our laboratory and checked routinely with the method of FISKE and SUBbarow where volume of blood was not restrictive (dog). The maximum discrepancy between these two methods, amounts to no more than $\pm 6 \%$. This accuracy applies also to the analysis of samples of orthophosphate in amounts differing up to one order of magnitude. Such an error is within the precision limits of the measuring instruments used. Numerous $P_{1}$ determinations on human sera were performed utilizing the old and the new enzymatic method and checked against results obtained in the hospital laboratories by the method of FISKE and Subbarow. Again, agreement was satisfactory, except for sera that exhibit very high alkaline phosphatase activity. Under such circumstances, both enzymatic methods show a high esterification rate and a continuous increase in $\Delta \mathrm{E}$ for $\mathrm{P}_{\mathrm{i}}$ was observed. Upon addition of an inhibitor of alkaline phosphatase, such as phenanthroline or theophylline, the situation is corrected. The determinations of $P_{i}$ on such sera have to be repeated, the inhibitor being included from the start in the cuvette mixture, to give a final concentration of $1 \mathrm{~mm}$. The $P_{1}$ values obtained by applying

Tab. 1

Analysis of native sera for $P_{i}$

\begin{tabular}{|c|c|c|c|c|}
\hline Species & $\begin{array}{c}\text { Amylase } \\
\text { (SomoGYI Units) }\end{array}$ & Glycogen*) & $\begin{array}{c}\mathbf{P}_{\mathbf{i}}, \mathbf{g} / \mathbf{l} \\
\text { Methods: } \\
\text { Triosephosphate }\end{array}$ & $\begin{array}{l}\text { FISKE and } \\
\text { SUBBAROW }\end{array}$ \\
\hline $\begin{array}{l}\text { Human, normal } \\
\text { Human, abnormal } \\
\text { Dog } \\
\text { Cat } \\
\text { Rabbit } \\
\text { Rat } \\
\text { Mouse }\end{array}$ & $\begin{array}{r}150 \\
3000 \\
1200 \\
1490 \\
6 \\
2650 \\
1550\end{array}$ & $\frac{31}{\overline{45}}$ & $\begin{array}{l}31 \\
24 \\
40 \\
45 \\
43 \\
93 \\
75\end{array}$ & $\begin{array}{l}30 \\
25 \\
40 \\
46 \\
44 \\
91 \\
76\end{array}$ \\
\hline $\begin{array}{l}\text { Rat, Fluoroacetate treated } \\
\text { ( } 3 \mathrm{mg} / \mathrm{kg}, \mathrm{i} . \mathrm{p} .)\end{array}$ & $\begin{array}{c}\text { before injection } \\
1 \mathrm{~h} \text { later } \\
2 \mathrm{~h} \text { later }\end{array}$ & $=$ & $\begin{array}{r}69 \\
42 \\
218\end{array}$ & $\overline{2}$ \\
\hline
\end{tabular}

*) For the glycogen method the reagents are mixed in the following proportions: $500 \mu 1$ triethanolamine-EDTA buffer pH 7.6 (triethanolamine $120 \mathrm{~mm}$, EDTA $12 \mathrm{mM}), 50 \mu \mathrm{l}$ glycogen $(2 \%), 10 \mu \mathrm{I} \mathrm{NADP}(40 \mathrm{~mm}), 5 \mu \mathrm{l}$ AMP $(50 \mathrm{~mm}), 5 \mu \mathrm{l}$ glucose-1,6-diphosphate (1.2 mM) and $30 \mu \mathrm{I} \mathrm{magnesium}$ acetate $(200 \mathrm{~mm})$. Each determination requires $600 \mu \mathrm{l}$ of this mixture, which with $\mathrm{H}_{2} \mathrm{O}, 20 \mu \mathrm{l}$ of serum and the necessary enzymes, add up to a final volume of $1.2 \mathrm{ml}$. Enzymes required are: $5 \mu 1$ glucose-6-phosphate dehydrogenase (1 ms enzyme protein/ml or $0.35 \mathrm{U}$ ), $5 \mu \mathrm{l}$ of phosphoglucomutase ( $2 \mathrm{mg}$ enzyme protein/ml) and $25-35 \mu \mathrm{l}$ of phosphorylase a ( $2 \mathrm{mg}$ enzyme protein/mi, which is prepared as follows: weigh an amount equivalent to $2 \mathrm{mg}$ enzyme protein of lyophylised phosphorylase a of Boehringer and dissolve it in $1 \mathrm{ml}$ of $0.5 \%$ glycogen $24 \mathrm{~h}$ before use). A reagent blank and a standard must be carried along with each set of determinations as described for triosephosphate method. 
this procedure, agree with those obtained by the use of deproteinised sera (method of FISKE and Subbarow). In experienced hands such observations are of diagnostic value.

The accompanying table illustrates some of our data. The first 2 examples are those obtained for human sera, normal and abnormal, regarding their respective amylase activity. Normal values for this enzyme in humans may reach up to 200 Somogri units. The abnormal serum has an unusually high amylase activity and was withdrawn from a patient suffering from severe pancreatitis. This serum, when analyzed by the glycogen method, appeared to contain practically no $\mathrm{P}_{1}$. Before the determination was terminated, extra glycogen was introduced into the cuvette and as a result, $\mathrm{P}_{1}$ present in the serum was esterified. Therefore, although the glycogen method is not applicable in cases of pancreatitis, it may be of diagnostic value.

The amylase values for sera of experimental animals quoted in the table, except for the rabbit, are all high and therefore the glycogen method can not be used. Results obtained by the triosephosphate method compare favorably with those of the method of Fiske and Subbarow.
Finally, the advantages of the method described may be exemplified by its application to a study on rats. Fluoroacetate, a known rodent poison, causes accumulation of citrate in various organs. As citrate binds $\mathrm{Ca}^{++}$, one might expect a change in the $\mathrm{P}_{1}$ level of blood. In the experiment quoted, blood was analyzed for $P_{1}$ before injection of fluoroacetate and at two subsequent intervals, as symptoms of poisoning developed and progressed. $0.1 \mathrm{ml}$ of blood removed by heart puncture yields an amount of serum sufficient for several micro-determinations. (We often draw as many as five samples and collect a sixth, larger one, when the animal is sacrificed.) In the fluoroacetate experiment, the blood $\mathrm{P}_{1}$ at first decreases and later increases sharply. Not all rats respond so dramatically to this poison, but this case was chosen to illustrate the reliability of the method in case of wide variations in the $P_{i}$ content of sera.

We gratefully acknowledge the competent assistance of Mrs. Meline Sepetjian who helped with the precipitation procedures for the removal of contaminating phosphates.

This work was supported by a grant from the Lebanese National Research Council.

\section{References}

1. Fawaz, E. N., L. Roth and G. FAwaz, Biochem. Z. 344, 212 (1966). - 2. Fiske, C. H. and Y. SubBarow, J. biol. Chemistry 66, 375 (1925). - 3. FAwAZ, G. and E. N. FAwAZ, Methods in phatma- cology edited by A. Schwartz, p. 515, Appleton-Century-Crofts, New York (1971).
Dr. Eva N. Fawaz Dept. Pharmacology School of Medicine American University of Beirut, Lebanon 